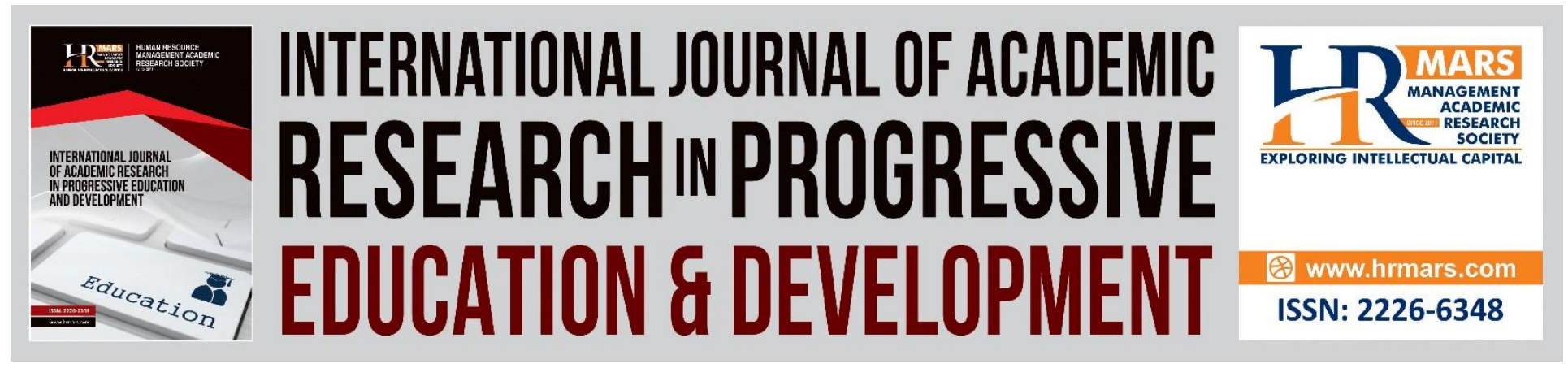

\title{
Mathematics Anxiety and Mathematics Motivation among Students in the Faculty of Science of a Public University in Malaysia
}

\section{Nuur Adila Mohammad Ali \& Norlizah Che Hassan}

To Link this Article: http://dx.doi.org/10.6007/IJARPED/v8-i4/6786

DOI:10.6007/IJARPED/v8-i4/6786

Received: 12 November 2019, Revised: 30 November 2019, Accepted: 11 December 2019

Published Online: 29 December 2019

In-Text Citation: (Ali \& Hassan, 2019)

To Cite this Article: Ali, N. A. M., \& Hassan, N. C. (2019). Mathematics Anxiety and Mathematics Motivation among Students in the Faculty of Science of a Public University in Malaysia. International Journal of Academic Research in Progressive Education and Development, 8(4), 952-963.

Copyright: (C) 2019 The Author(s)

Published by Human Resource Management Academic Research Society (www.hrmars.com)

This article is published under the Creative Commons Attribution (CC BY 4.0) license. Anyone may reproduce, distribute, translate and create derivative works of this article (for both commercial and non-commercial purposes), subject to full attribution to the original publication and authors. The full terms of this license may be seen at: $\underline{\text { http://creativecommons.org/licences/by/4.0/legalcode }}$

\section{Vol. 8(4) 2019, Pg. 952 - 963}

Full Terms $\&$ Conditions of access and use can be found at http://hrmars.com/index.php/pages/detail/publication-ethics 


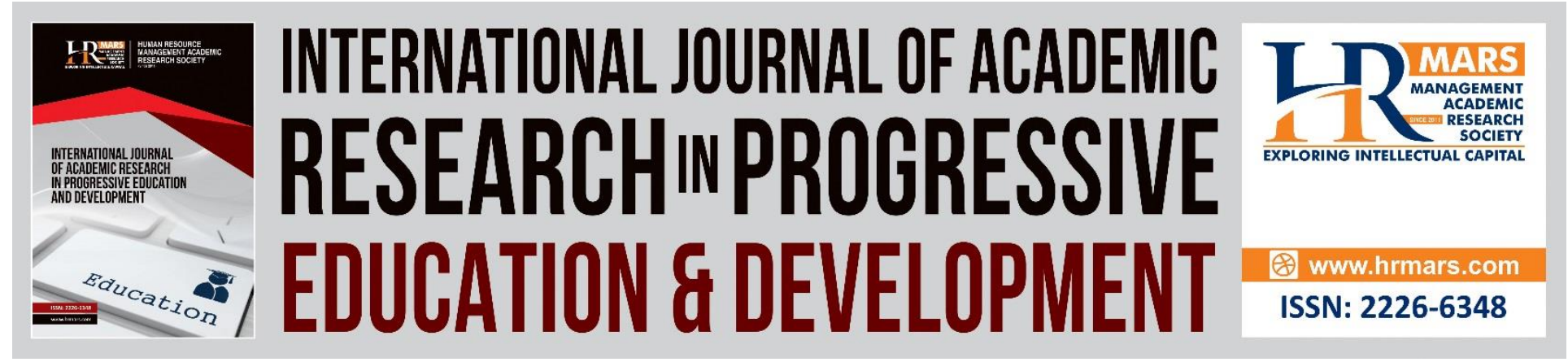

\title{
Mathematics Anxiety and Mathematics Motivation among Students in the Faculty of Science of a Public University in Malaysia
}

\author{
Nuur Adila Mohammad Ali \& Norlizah Che Hassan \\ Faculty of Educational Studies, University Putra Malaysia, 43450, Serdang, Malaysia
}

\begin{abstract}
Mathematics anxiety and Mathematics motivation has been the target of most psychological and educational research in the past few years. Many studies showed that math anxiety and math motivation is an influence on students' achievement in school. In fact, the performance of students especially in Math are weak not only in secondary school but in university level as well, even though they have spent almost eleven years in formal education system. The aims of this study is to identify the differences on math anxiety and math motivation based on gender and to investigate the relationship between math anxiety and math motivation among students in the faculty of science of a public university in Malaysia. The sample consisted of 104 (23 male and 81 female) undergraduate students in the Faculty of Science. The instruments used to measure the math anxiety level and math motivation are Mathematics Anxiety Rating Scale (MARS) and The Motivated Strategies for Learning Questionnaire (MSLQ). The Alpha Cronbach scored based on the pilot test shown the score value of Math anxiety is 0.87 and Math Motivation 0.85 . The data were analyzed using Pearson correlation and independent-samples ttests (SPSS 11.5). The results showed a significant moderate correlation between math anxiety and math motivation. It is also revealed that there were significant gender differences between male and female in math anxiety and math motivation. Hence, the findings may help in better understanding of mathematics-learning processes and provide important insights for intervention or remedial programs that targeting in improving mathematics-learning process of the students.
\end{abstract}

Keywords: Mathematics Anxiety, Mathematics Motivation, Public University Students.

\section{Introduction}

Mathematics is one of the most important subject and compulsory subjects in primary and secondary schools, especially for those who are in science stream. Mathematics is associated with promising future academic as well as career opportunities. Almost all careers nowadays required Mathematics, and Mathematics is an important subject that related with scientific, 
industrial, technology and social progress of society. However, Mathematics seems to be a problem to many learners, and math is one of the subjects that students might prefer to avoid. Mathematics is troublesome for some people and this can cause anxiety to them. Failure in mathematics subject is a global issue as well as a critical issue in developing nation (Mohamed \& Tarmizi, 2010). Not all students can perform well in Mathematics. Some are having problems with Mathematics and the students who are outwardly expresses a negative feeling towards Math seldom performed well in mathematical skills (Jenkins, 2006).

According to Mason, Stacey and Burton (2010) mathematical thinking will support science, technology, economics and development in economy. Although Math is important for career and future, Math is always seen as a difficult subject. Therefore, many actions and policies have been implemented by the government to ease these problems. A mission to ensure 60:40 student ratio in Malaysia -" to represent $60 \%$ science stream and $40 \%$ arts stream students in the upper secondary school, has been established since year 1994 to realize the 2020 Vision and the National Science and Technology Policy (Mok, 2008). According to Salleh (2014) "Generally, this policy aims to encourage science students' participation in the field of health science, engineering, science education, ICT and other science related courses". The Malaysian Ministry of Education (MOE) was optimistic that the ratio of 60:40 between science and arts stream students can be achieved by the year 2010 through students' early exposure towards integrated science and technology curriculum. Greater emphasis is being placed on industrial and technological development. As a result, students are encouraged to take up science related subjects. One subject in particular is Mathematics" (2014, p. 223). Today, Math plays a fundamental role in economic development of a country. Thus, to meet the scientific and technological advancement, we need citizens with good performance in Mathematics. Yet, the performance of the students in mathematics have not improved and the students perceived Mathematics as one of the most challenging subjects (Jenkins, 2006).

Mathematics problems is very common among students in primary, secondary as well as university students. For a university students, the class schedule is quite tight. For those who are having problems with Mathematics, they will tend to ignore the course or even worst they might fail the course and finally drop the course. Unfortunately, the performance of students especially in Mathematics is weak not only in secondary schools but in universities even though they have spent almost eleven years in the Malaysian education system (Noor Erma \& Leong, (2014). In order to help the students cope with this problem, they have to know their level of anxiety and motivation towards math. According to Bidin et al, (2005), majority of Malaysian students have moderate level of Mathematics anxiety. Lazarus (1974) believed that "Mathematics anxiety were rooting from the elementary and secondary schools". Various factors have been deduced for poor performance of students in Mathematics. For example, the student's level of interest in Mathematics is reported to be related to the volume of work to be completed, student's task orientation and skill acquisition, student's personality and self-concept, motivation, confidence level and anxiety (Ngasiman, 2014). Even many students had their first negative experience with math instruction as early as standard 3 and 4 . This is cause for concern, considering that tertiary students may bring these negative thoughts to their university level. 
There are various types of mathematics anxiety that related to attitudes towards Mathematics, learning preferences, learning objectives and strategies. Anxiety is a state of emotions related by the qualities of fear and dread (Ho et. al, 2000). Math anxiety is related to poor academic performance in Mathematics and negative attitudes towards Mathematics subject which resulted in students tend to avoid learning this subject. Mathematics anxiety has become catastrophe for debilitating test stress, low self-confidence, feared of failure and negative attitudes towards learning Mathematics. Students who have high level of mathematics anxiety will have lower level of mathematics achievement. Ho et al. (2000), reported that Mathematics anxiety seriously constraints performance in mathematical tasks and reduction in anxiety is consistently associated with improvement in achievement". Meanwhile according to Stuart (2000), "lack of confidence when working in mathematical situations is the cause of mathematics anxiety. Many students think that mathematics is not important to personal development thus they did not care to think mathematically" (2000, p. 331). It is very important to acquire the skills that also related with mathematical thinking and mathematics motivation, how problem solving provide enormous opportunities for the development of mathematical thinking, mathematical knowledge and the ability to use it is crucial especially when entering working field. Similarly, math motivation has extensive impacts on academic achievement (Good \& Aronson, 2003). According to Gunderson, Park, Maloney, Beilock \& Levine, (2018) "Like math anxiety, motivational frameworks have important, well-established impacts on academic achievement". (2018, p. 25). Basically, increasing students' motivation in class is an important issue for teachers, especially when math achievement is related with students' math motivation and behaviour, thus, math motivation plays a role in math performance.

Previous research has been done in order to probe into mathematics anxiety and mathematics motivations among tertiary student. Effandi and Norazah (2008) studied about the influence of mathematics anxiety on tertiary students as related to motivation and achievement, they have found that students who have higher mathematics anxiety scored significantly lower in achievement. Students who experience higher anxiety level will show negative attitude towards Mathematics. This has been supported by several researches that suggested high achieving students are less anxious (Tella, 2007). The researcher also found that the effect of mathematics anxiety on motivations was significant, students who have lower level of mathematical motivation are the students who have higher level of mathematics anxiety. This is not surprising because there is a strong correlation between mathematics anxiety and motivation. This means that students with higher level of mathematics anxiety will be less motivated in Mathematics. According to Wang et al, (2015) who investigated math anxiety and math motivation, noted a complex pattern of results. "For children who have low levels of math motivation, increased level of math anxiety was associated with poor performance. For children who have high math motivation, the relationship between math anxiety and performance resembled an inverted $U$ shape graph. The anxiety level increased with performance until it reached the peak levels. When anxiety level increased beyond this peak level, math performance decreased" (2015, p. 1864). However, according to Singh, Granville, and Dika 
(2002), motivation plays a vital role to overcome the anxiety towards mathematics. Their study reported that the attitude towards mathematics was affected by motivational factors.

Thus, based on the previous research, math anxiety had influenced many aspects of learning and teaching mathematics (Mohamed \& Tarmizi, 2010; Mok, 2008). According to Mohamed and Tarmizi (2010), mathematical knowledge and the ability to use this knowledge are critical in pursuing into working field. Before going into working phase, students should be equipped with substantial knowledge in order to ensure their best performance in their career. Hence, it is crucial to study the anxiety towards mathematics and motivation among students especially in Malaysian Public University. This study is very important because it also seek to identify the factors contributing to anxiety in mathematics subject such as parents, peers and society. By identifying these factors, it can help students to avoid the factors that can lead them to mathematics anxiety. It is very important for students to avoid mathematics anxiety since it might cause them to dislike Mathematics and this can lead to a huge problem in future when they are entering the working phase. Therefore, it is the aims of the study to identify the gender differences on Math anxiety and Math motivation, and to examine the relationship between math anxiety and math motivation among UPM students (public university).

\section{Methods}

The research design of the study was a correlational survey design. Researcher randomly selected the sample of students from the Faculty of Science, UPM. The selected sample are the students from Bachelor of Science with Education majoring in Biology, Chemistry, Physics and Mathematics. The targeted population or the total number of second year students at the Faculty of Science for year 2015/2016 was 262. Therefore, the calculated sample size using the formula from Krejcie and Morgan (1970) are 104 participants. Hence, the researcher randomly selected 104 participants through cluster random sampling. The questionnaires implemented and modified based on the design and appropriateness of the objectives for this study. The original questionnaires were based on the instrument of Mathematics Anxiety Rating Scale (MARS) authored by Richardson and Suinn (1972) and Pintrich, Smitch, Garcia, and McKeachie (1991) for The Motivated Strategies for Learning Questionnaire (MSLQ). The Cronbach Alpha scored based on the pilot test shown the score value as follow; Math anxiety 0.87 and Math Motivation 0.85 .

\section{Results and Discussion}

This section presents results and discussion on the findings of the study. It is shown in this section, the data analysis of respondents' demographic, data analysis of gender differences on math anxiety and math motivation, and data analysis of correlation between math anxiety and motivation.

\section{Respondents Demographic}

The demographic characteristics of the sample includes participants' age, program, gender and race. The age range of the students, showed that group of students below 19 years old consist of 2 participants (1.9\%), age $19-20$ are 82 students (78.8\%) and age $21-22$ are 20 
Vol. 8, No. 4, 2019, E-ISSN: 2226-6348 @ 2019 HRMARS

students (19.2\%). For the gender distribution, the data showed that $23(22.1 \%)$ students are male and $81(77.9 \%)$ are female. The sample of students are derived from four main programs at the Faculty of Science, UPM. They are students from Bachelor of Science with Education (Hons) Major in Biology 25 participants (24\%); Major in Chemistry 25 participants (24\%); Major in Physics 24 participants (23.1\%) and Major in Mathematics 30 participants (28.8\%). The data showed that Malay group consists of 93 participants (89.4\%), which is the highest among other groups, Indian group consists of 1 participant (1.0\%); Chinese group consists of 2 participants (1.9\%) while for those who categorized as "others" consists of 8 participants (7.7\%). This group "others" was made up by native group such as Bajau, Pagan, Iban and Kadazan from Eastern Malaysia. Table 1 below presents the descriptive analysis of demographic background of the respondents such as gender, age group, program and race.

Table 1. Demographic data of the Respondents

\begin{tabular}{lll}
\hline \hline Variables & Frequency & Percent \\
\hline Gender & 23 & 22.1 \\
Male & 81 & 77.9 \\
Female & & \\
Age Group & 82 & 78.8 \\
$19-20$ & 20 & 19.2 \\
$21-22$ & & \\
Bacelor of Science in Education & 25 & 24 \\
Major Biology & 25 & \\
Major Chemistry & 24 & 23.1 \\
Major Physics & & 28.8 \\
& & \\
Race & 93 & 89.4 \\
Malay & 1 & 1.0 \\
Indian & 2 & 1.9 \\
Chinese & 8 & 7.7 \\
Others &
\end{tabular}

\section{Differences on Math Anxiety and Math Motivation based on Gender}

An independent sample t-test was conducted to differentiate between gender and mathematics anxiety of students. From table 2 below, it was found a significant different $(p<.01)$ between male and female's mathematics anxiety. A significant difference in the mean of students' mathematics anxiety for male students $(M=3.3593, S D=0.57209)$ and female students $(\mathrm{M}=3.5939, \mathrm{SD}=0.64381 ; \mathrm{t}(102)=1.579, \mathrm{p}=*$.011). The mean difference, .23462 showed that the female students had higher mathematics anxiety compared to male students 
Table 2. Independent Sample t-test between Gender and Math Anxiety

\begin{tabular}{|c|c|c|c|c|c|c|c|}
\hline $\begin{array}{c}\text { Gende } \\
r\end{array}$ & $\mathrm{~N}$ & $M$ & SD & $\begin{array}{c}\text { Mea } \\
n \\
\text { diffe } \\
\text { renc } \\
\mathrm{e}\end{array}$ & DF & $t$ & $P$ \\
\hline Malo & 2 & 3.359 & .5720 & & & \multirow{4}{*}{1.579} & \multirow{4}{*}{ *.011 } \\
\hline Ivlale & 3 & 3 & 9 & .234 & 10 & & \\
\hline Femal & 8 & 3.593 & .6438 & 62 & 2 & & \\
\hline $\mathrm{e}$ & 1 & 9 & 1 & & & & \\
\hline
\end{tabular}

The findings of this study show that there is a significant different $(p<.01)$ between male and female's mathematics anxiety. A significant difference in the mean of students' mathematics anxiety for male students $(M=3.3593, S D=0.57209)$ and female students $(M=3.5939, S D=$ $\left.0.64381 ; \mathrm{t}(102)=1.579, \mathrm{p}={ }^{*} .011\right)$. The mean difference, .23462 showed that the female students had higher mathematics anxiety compared to male students. In previous study, female students showed a good performance in mathematics compared to male students. They also show a positive attitude toward mathematics compared to male students. This is because the anxiety towards mathematics leads to a good behaviour so that they will perform well in mathematics subject (Singh et al, 2002). Meanwhile, Asante (2012) study reported that female students scored lower confident level compared to male students. When doing mathematics tasks, they feel nervous and fear if they might not performed well and not get a good result. Thus, female students have higher anxiety level compared to male student. In contrast to study by Mata, Monteiro, and Peixoto (2012), the study noted that male students have higher self-concept compared to female students. Due to their higher self-concept, the male students performed well in mathematics even though they did not give full attention when studying mathematics in class. However, this current study is inconsistent with the study by Karjanto and Yong (2013), which reported the levels of mathematics anxiety did not differ by sex or language background of the early undergraduate students.

An independent sample t-test was conducted to compare between gender and math motivation of students. From the table 3 below, there was a significant different $(p<.01)$ between male and female's mathematical motivation. A significant difference in the mean of students' mathematical motivation for male students $(M=3.2276, S D=0.55785)$ and female students ( $M$ $=3.4321, \mathrm{SD}=0.56092 ; \mathrm{t}(102)=1.545, \mathrm{p}=* .012)$. The mean difference, .20448 showed that the female students had higher motivation towards mathematics compared to male students. 
INTERNATIONAL JOURNAL OF ACADEMIC RESEARCH IN PROGRESSIVE EDUCATION AND

DEVELOPMENT

Vol. 8, No. 4, 2019, E-ISSN: 2226-6348 @ 2019 HRMARS

Table 3. Independent Sample t-test between Gender and Math Motivation

\begin{tabular}{cccccccc}
\hline $\begin{array}{c}\text { Gend } \\
\text { er }\end{array}$ & $N$ & $\mathrm{M}$ & SD & $\begin{array}{c}\text { Mean } \\
\text { differe } \\
\text { nce }\end{array}$ & DF & $t$ & $\mathrm{P}$ \\
\hline Male & 23 & $\begin{array}{c}3.227 \\
6\end{array}$ & $\begin{array}{c}.5578 \\
5\end{array}$ & & 10 & & \\
Femal & & 3.432 & .5609 & .20448 & 2 & 1.545 & $* .012$ \\
$\mathrm{e}$ & 81 & 1 & 2 & & & & \\
\hline
\end{tabular}

Independent sample t-test shows a significant different $(p<.01)$ between male and female's mathematical motivation. A significant difference in the mean of students' mathematical motivation for male students $(M=3.2276, S D=0.55785)$ and female students $(M=3.4321, S D=$ $0.56092 ; \mathrm{t}(102)=1.545, \mathrm{p}=* .012)$. The mean difference, .20448 showed that the female students had higher motivation towards mathematics compared to male students. This study noted that the differences in gender affect the motivation in mathematics. This was in line with the study by Middleton and Spanias (1999), that noted when students have intrinsic motivation they will enjoy with their study and they will show positive attitude towards something they are up to and female were more intrinsically motivated compared to male that were more extrinsically motivated. Thus, Singh, Granville and Dika (2002) have reported that mathematics attitude was affected by motivational factors. When students have higher level of positive attitude towards the subject, their motivation towards the subject will also be higher. Thus, they will perform well in the subject.

Table 4. Correlation between Math Anxiety and Math Motivation

\begin{tabular}{|c|c|c|c|}
\hline & & Math motivation & $\begin{array}{l}\text { Math } \\
\text { Anxiety }\end{array}$ \\
\hline \multirow{3}{*}{$\begin{array}{l}\text { Math } \\
\text { Motivatio } \\
n\end{array}$} & $(r)$ & 1 & $.409^{* *}$ \\
\hline & Sig. (2-tailed) & & .000 \\
\hline & $\mathrm{N}$ & 104 & 104 \\
\hline \multirow{3}{*}{$\begin{array}{l}\text { Math } \\
\text { Anxiety }\end{array}$} & $(r)$ & $.409^{* *}$ & 1 \\
\hline & $\begin{array}{l}\text { Sig. } \\
\text { tailed })\end{array}$ & .000 & \\
\hline & $\mathrm{N}$ & 104 & 104 \\
\hline
\end{tabular}

**.Correlation is significant at 0.01 level (2 tailed) 
Pearson's Correlation Coefficient ( $r$ ) was used to analyse the relationship between math anxiety and math motivation among students faculty of science, UPM. Table 4 above showed results of the correlation $\left(r=.409, r^{2}=.17, p=.000\right)$ between math anxiety and math motivation. As can be seen from the table, the math anxiety has a significant correlation with math motivation. The value of $r=.409$ indicated a moderate significant positive relationship between math anxiety and math motivation.

The finding shows that there is a significant relationship between math motivation and math anxiety among students at Faculty of Science, UPM. Pearson's Correlation Coefficient ( $r$ ) was used to analyse the relationship between math anxiety and math motivation among the students. The results show the correlation $\left(r=.409, r^{2}=.17, p=.000\right)$ between math anxiety and math motivation. As can be seen in table 4, math motivation has a significant correlation with math anxiety. The value of .409 which indicates that there is a moderate significant relationship between math motivation and math anxiety. Previously, past research has reported that when people are doing their specific task, the attitude towards the tasks is depend on how the people feel about the task. Motivation exist as part of people's goal structures, their belief about what is important and determine whether or not one will engage in a given chance (Asante, 2012).

Based on the previous study by Zakaria and Nordin (2008), reported that students who have higher mathematics anxiety scored significantly lower in achievement. Students who experience higher anxiety will show negative attitude towards mathematics, and mathematic attitude was affected by motivational factors. Students who have higher motivation towards the subject will perform better and students who have lower motivation level towards that subject will show poor performance in the subject (Singh et al, 2002; Malik \& Manaf, 2018; Novalino, Heryanto, 2018). Students who have lower level of motivation in mathematics are due to bad experiences in mathematics for example fierce mathematic teachers, punishment they get in class, get bad result and others. Thus, this will lead the students to have lower level of mathematical motivation. However, according to Wang et al. (2015), "efforts solely focusing on reducing math anxiety alone may not be proven to be effective for all students even though math anxiety is very crucial for children in their learning process. Motivation may help overcome the detrimental effects of math anxiety. A moderate level of math anxiety was associated with high math performance among students who reported high math motivation, that is, among students who reported that they valued math and embraced math challenges. However, high math anxiety appears to be linked with low math performance" (2015, p 1872). As such, math motivation can be an important soothe to the negative effects of math anxiety.

Academic achievement is very important as it can help the students to enter higher level of education or not. When the achievement is good, then the students have higher chances to study in great institution meanwhile if they did not perform well, they might not have opportunities to further their studies. Besides, parents will pay more attention towards their children math achievement and try to build a strong relationship as well as better learning environment at home. This will make their children enjoy when studying at home. When they enjoy math, their motivation towards math learning will be better. This, can avoid student's 
phobia to math as most of students fear to learn math. When having positive emotion towards math, the motivational level will be high, and this can trigger their happiness (emotion to learn). Thus, the learning process can be smooth and the students can easily understand what they are learning. School teachers should practice positive role in raising the students and avoid all of the negative things and thinking. In fact, math teachers must pay closer attention to the fact that the requirements of the female and male learners may be different in the classroom. Apart from that, parent also need to play an important role in creating interest of math among their children.

\section{Conclusion}

The present study aims to examine the correlation between math anxiety and math motivation. The results revealed a significant moderate correlation between math anxiety and math motivation. It is also found that there are significant gender differences between male and female in math anxiety and math motivation. It is also reported by other research that when math anxiety level decreased, math scores increased and improved (Wang et al., 2015; Zaini, 2018)

Mathematics anxiety can be reduced by using some special methods in teaching and psychological intervention, which is applicable in the pedagogical domains and the improvement of curriculum practices. Thus, it can be a useful factor in increasing the quality of learning. Hence, these findings may help better understanding of mathematics-learning processes and provide important insights for intervention programs to enhance mathematics-learning process. In conclusion, math anxiety is common in general and it has been rooting in the students from primary to tertiary level. Today, the needs of society require a greater need for mathematics. In order to reduce math anxiety, mathematics must be regarded in positive perception by students. Therefore, teachers must reassess traditional teaching methods which often do not necessarily fit the students' learning with math learning that could stimulate and attract students' attention in learning math. Teachers must use a variety of teaching styles accordingly to ensure learning math is fun and enjoyable as math motivation can be an important buffer to the negative influence of math anxiety. As a result, once young children see math as fun, they will enjoy it, and, the joy of mathematics could remain with them throughout the rest of their lives. Thus, further studies are needed to compare math anxiety and motivation in various fields of study and it is worth mentioned that further research should be conducted on the math anxiety and math motivation in different stages of academic levels, difference kinds of anxiety and across the other states.

\section{Acknowledgements}

We are very grateful to all the participants for their contribution to this research, and to thosel who had contributed to this study.

\section{Corresponding Author}

Norlizah Che Hassan (Phd) is a senior lecturer at Faculty of Educational Studies, University Putra Malaysia, 43450, Serdang, Malaysia. Email: norlizah@upm.edu.my 
INTERNATIONAL JOURNAL OF ACADEMIC RESEARCH IN PROGRESSIVE EDUCATION AND

DEVELOPMENT

Vol. 8, No. 4, 2019, E-ISSN: 2226-6348 @ 2019 HRMARS

\section{References}

Asante, K. O. (2012). Secondary Students' Attitudes towards Mathematics. IFE PsychologIA, 20, 121-133.

Bessant, K. C. (1995). Factors associated with types of mathematics anxiety in college students, Journal for Research in Mathematics Education, 26(4), 327-345.

Bidin, J., Noorzila, S. \& Kasim, Z. (2005). Kegelisahan Matematik dalam kalangna pelajar menengah rendah di Perlis. Prosiding Simposium Kebangsaan Sains Matematik ke XIII.

Blackwell, L. S., Trzesniewski, K. H., \& Dweck, C. S. (2007). Implicit theories of intelligence predict achievement across an adolescent transition: A longitudinal study and an intervention. Child development, 78(1), 246-263.

Good, C. \& Aronson J. (2003).The development of stereotype threat and its relation to theories of intelligence: Effects on elementary school girls' mathematics achievement and task choices. Unpublished manuscript Columbia University, New York.

Gunderson, E. A., Daeun P., Erin, A., Maloneyc, S., Beilockd, L., \& Susan C. L. (2018). Reciprocal relations among motivational frameworks, math anxiety, and math achievement in early elementary school. Journal of Cognition and Development, vol. 19, no. 1, 21-46 https://doi.org/10.1080/15248372.2017.1421538

Ho, H. Z., Senturk, D., Lam, A. G., Zimmer, J. S., Hong, S., Okamoto, Y., Chiu, S. Y., Nakazawa, Y., \& Wang, C. P. (2000). The affective and cognitive dimensions of math anxiety: A crossnational study. Journal for Research in MathematicsEducation, 31, 362-379.

Jenkins, N. (2006). Factors that Influence Mathematics Attitudes. Summative Projects for MA Degree. 8. http//:digitalcommons.unl.edu/mathmidsummative/8

Karjanto, N., \& Yong, S. T. (2013). Test anxiety in mathematics among early undergraduate students in a British university in Malaysia. European Journal of Engineering Education, 38(1), 11-37. http://dx.doi.org/10.1080/03043797.2012.742867

Krejcie, R. V. \& Daryle W. M. (1970). Determining sample size for research activities. Educational and Psychological Measurement 1970, 30, 607-610.

Lazarus, M. (1974). Mathephobia some personal speculation. National Elementary Proncipal, 53, 16-22.

Malik, S., \& Manaf, U. K. (2018). The Effect of Orientation and Mobility Curriculum on the Academic Achievement of Visually Impaired Children among Public and Private Institutions of Lahore. Multilingual Academic Journal of Education and Social Sciences, 6(1), 66-75.

Mason, J., Stacey, K. \& Burton, L. (2010). Thinking Mathematically (2th edition). Edinburgh: Pearson.

Mata, L., Monteiro, V., \& Peixoto, F. (2012). Attitudes towards mathematics: Effects of individual, motivational, and social support factors. Child Development Research, 1-10. https://doi.org/10.1155/2012/876028

Middleton, J., \& Spanias, P. A. (1999). Motivation for achievement in mathematics: Findings, generalizations, and criticisms of the research. Journal for Research in Mathematics Education, 30(1), 65-88.

Mohamed, S. H., \& Tarmizi, R. A. (2010). Anxiety in Mathematics Learning Among Secondary School Learners: A Comparative Study between Tanzania and Malaysia. Procedia - Social and Behavioral Sciences 8:498-504. 
Mok, S. S. (2008). Ilmu Pendidikan Untuk KPLI (Sek. Rendah:Komponen 1 \& 2). Psikologi Pendidikan \& Pedagogi. Kumpulan Budiman Sdn. Bhd., Subang Jaya.

Ngasiman, N. H. (2014). Kesan kaedah pembelajaran koperatif terhadap pencapaian pelajar dalam mata pelajaran Matematik. Tesis ljazah Sarjana Pendidikan Teknikal dan Vokasional, Universiti Tun Hussein Onn, Malaysia.

Noor, E., \& Leong K. E. (2014). Hubungan Antara Sikap, Minat, Pengajaran Guru Dan Pengaruh Rakan Sebaya Terhadap Pencapaian Matematik Tambahan Tingkatan 4. Jurnal Kurikulum \& Pengajaran Asia Pasifik. Januari 2014, Bil. 2 Isu 1.

Novalino, Heryanto. (2018). Effect of Competence and Work Loads on Motivation and Its Impact on the Performance of Budget Users in the Regional Working Unit of Padang City, International Journal of Academic Research in Accounting, Finance and Management Sciences 8 (4): 61-69.

Pintrich, P., Smith, D., García, T., \& McKeachie, W. (1991). A manual for the use of the motivated strategies for learning questionnaire (MSLQ). Ann Arbor, MI: University of Michigan.

Richardson, F. \& Suinn, R. (1972). The Mathematics Anxiety Rating Scale: Psychometric data. Journal of Counseling Psychology, 19, 551-554Lewis, A. (1970). The ambiguous word 'anxiety". International Journal of Psychiatry, 9, 62-79.

Salleh, S. (2014). Malaysian students' motivation towards Physics learning. European Journal of Science and Mathematics Education Vol. 2, No. 4, 223-232.

Singh, K., Granville, M., \& Dika, S. (2002). Mathematics and Science Achievement: Effects of Motivation, Interest, and Academic Engagement. Journal of Educational Research, 95, 323-332.

Stuart, V. B. (2000). Math curse or math anxiety? Teaching Children Mathematics, ERICS; v6 n5 p330-35.

Tella, A. (2007). Work Motivation, Job Satisfaction, and Organisational Commitment of Library Personnel in Academic and Research Libraries in Oyo State, Nigeria, C.O. Ayeni, S.O. Popoola. Library Philosophy and Practice 2007: (April).

Wang, Z., Sarah, L., Sara, A. H., Ian, M. L., Lee, A. T., Yulia, K., Michèle, M., Mazzocco, M., Robert, P., and Stephen A. P. (2015). Is Math Anxiety Always Bad for Math Learning? The Role of Mathematics Motivation. https://doi.org/10.1177/0956797615602471

Zaini, N. (2018). The Relationship between Multiple Intelligence on the Performance of Arts Stream Students in Linear and Non-Linear MUET Reading Component. International Journal of Academic Research in Progressive Education and Development, 7(4), 80-94.

Zakaria, E, \& Nordin N. M. (2008). The effects of Mathematics anxiety on Matriculation students as related to motivation and achievement. Eurasia Journal of Mathematics, Science \& Technology Education, 4 (1), 27-39.

Zimmerman, G. M., \& Carter, R. (2014). Do school disciplinary policies have positive social impacts? Examining the effects of school policies on the relationship between personal and peer delinquency. Journal of Criminal Justice, 42: 54-65. 